Diversity of Research in Health Journal / Revue de la Diversité de la Recherche en Santé

Vol 4, January/ Janvier 2021 - ISSN: 2561 -1666 DOI : 10.28984/drhj.v4i1.336

\title{
Reading Comprehension Abilities in the Anglophone Aging Population with Post-Secondary Education
}

\section{Bérubé \& S. Laurence}

DRHJ/RDRS 2021, 4, pp. 122-140

Dominique Bérubé,

Graduate Student in M.Sc.S., dominique.berube@gmail.com

School of Speech-Language Pathology, Faculty of Health

Laurentian University, Sudbury (ON), Canada.

Laurence Sophie, Ph.D.

Assistant Professor, slaurence@laurentian.ca

School of Speech-Language Pathology, Faculty of Health

Laurentian University, Sudbury (ON), Canada.

\begin{abstract}
Literacy skills such as reading comprehension are essential in order to understand written information and complete daily tasks. Low literacy skills are common in the aging population thus affecting quality of life, independence and social integration. Reading comprehension is a complex activity that requires processing at many different levels. According to Kintsch's construction-integration model, three levels of representations of a text must be achieved in order to fully comprehend a text. Previous studies often considered the aging population as a single group and compared this group to young adults. However, few studies examined the variability in reading comprehension abilities within the aging population. Studies examining the variability in the construction of a situation model in older adults are even more scarce. The main objective of this study is to examine the effect of age on reading comprehension abilities at the surface model, text-based model and situation model in the aging population with high education level.

Participants were recruited in northern Ontario and were grouped into three age intervals (60-69 years; 7079 years; $\geq 80$ years). Participants' cognitive functions were assessed using the Montreal Cognitive Assessment (MoCA) and health literacy was assessed using the Short Test of Functional Health Literacy in Adults (STOFHLA). Reading comprehension abilities were evaluated using the Woodcock Reading Mastery Tests - third edition (WRMT-III) as well as the Gray Oral Reading Test - fifth edition (GORT5).

Results indicated no significant differences in performance of reading comprehension abilities among the three age groups at the surface level, text-based level, and situation model level of reading comprehension. These findings suggest no age-related effect on reading comprehension abilities in adults with high levels of education. The lack of differences observed may be explained by the absence of differences in cognitive functions between the three age groups as well as the high level of education which may have acted as a protective factor. Future studies should examine reading comprehension in Anglophone adults with lower levels of education to better understand whether education is a protective factor against a decline in reading comprehension abilities in the aging population.
\end{abstract}

Key words: Reading comprehension, Aging population, Education, Kintsch's construction-integration model

\section{Résumé}

Les compétences en litéracie, telles que la compréhension en lecture, sont essentielles pour comprendre les informations écrites et accomplir les tâches quotidiennes. Les faibles capacités en litéracie sont courantes chez la population vieillissante, ce qui affecte la qualité de vie, l'indépendance et 
Diversity of Research in Health Journal / Revue de la Diversité de la Recherche en Santé Vol 4, January/ Janvier 2021 - ISSN: 2561 -1666 DOI : 10.28984/drhj.v4i1.336

l'intégration sociale. La compréhension de la lecture est une activité complexe qui nécessite un traitement à de nombreux niveaux. Selon le modèle de construction-intégration de Kintsch, trois niveaux de représentation d'un texte doivent être atteints pour comprendre pleinement un texte. Les études précédentes considéraient souvent la population vieillissante comme un groupe unique et comparaient ce groupe à de jeunes adultes. Cependant, peu d'études ont examiné la variabilité des capacités de compréhension en lecture au sein de la population vieillissante. Les études examinant la variabilité dans la construction d'un modèle de situation chez les adultes âgés sont encore plus rares. L'objectif principal de cette étude est d'examiner l'effet de l'âge sur les capacités de compréhension en lecture au niveau du modèle de surface, du modèle basé sur le texte et du modèle de situation chez la population vieillissante ayant un niveau d'éducation élevé. Les participants ont été recrutés dans le nord de l'Ontario et ont été regroupés en trois intervalles d'âge (60-69 ans ; 70-79 ans ; $\geq 80$ ans). Les fonctions cognitives des participants ont été évaluées à l'aide du Montreal Cognitive Assessment (MoCA) et la litéracie en santé a été évaluée à l'aide du Short Test of Functional Health Literacy in Adults (STOFHLA). Les capacités de compréhension en lecture ont été évaluées à l'aide du Woodcock Reading Mastery Tests - troisième édition (WRMT-III) ainsi que du Gray Oral Reading Test - cinquième édition (GORT5). Les résultats n'ont pas indiqué de différences significatives dans la performance des capacités de compréhension en lecture entre les trois groupes d'âge au niveau de la surface, au niveau du texte et au niveau du modèle de situation de la compréhension en lecture. Ces résultats ne suggèrent aucun effet lié à l'âge sur les capacités de compréhension en lecture chez les adultes ayant un niveau d'éducation élevé. L'absence de différences observées peut s'expliquer par l'absence de différences dans les fonctions cognitives entre les trois groupes d'âge ainsi que par le niveau élevé d'éducation qui a pu agir comme un facteur de protection. De futures études devraient examiner la compréhension en lecture chez les adultes anglophones ayant un niveau d'éducation plus faible afin de mieux comprendre si l'éducation est un facteur de protection contre une baisse des capacités de compréhension en lecture chez la population vieillissante.

Mots clés : Compréhension en lecture, Population âgée, Éducation, Modèle de construction-intégration de Kintsch

\section{Introduction}

Literacy skills such as reading comprehension are necessary in order to understand written information and complete many daily tasks. Low literacy skills are often associated with poor health status (Peng, Valpreda \& Lechelt, 2015; Rootman \& Ronson, 2005; Seccombe, Lockwood, \& Reder, 2005; Stormacq, Van den Broucke \& Wosinski, 2019; Zheng et al. 2018). Individuals with low literacy skills are more likely to misunderstand written medical instructions, have more difficulty accessing healthcare, understanding medical prescriptions, and also communicating to medical professionals (Peng et al. 2015; Rootman \& Ronson, 2005; Seccombe et al., 2005). Low literacy skills are not only associated with poor health status but also with an overuse or inappropriate use of health care facilities (Rootman \& Ronson, 2005). Literacy skills, and particularly reading comprehension, are a vital component in maintaining a good quality of life, independence, as well as social integration.

Many models have been created to explain the complex process of reading comprehension. Among these models is Kintsch's (1998) construction-integration model. This model is composed of three levels of representations of a text and each of these must be achieved in order to fully comprehend a text. First, the reader must access the surface level - also known as the linguistic level - meaning they must understand the words themselves and their meaning. The next level is the text-based level, otherwise known as the conceptual level of representation. This level is directly derived from the text and is 
Diversity of Research in Health Journal / Revue de la Diversité de la Recherche en Santé Vol 4, January/ Janvier 2021 - ISSN: 2561 -1666 DOI : 10.28984/drhj.v4i1.336

divided into the microstructure and the macrostructure of the text. The microstructure is the local structure of the text and is composed of the words and phrases themselves whereas the macrostructure is the global structure of the text and it refers to theme, topic, and genre. To achieve deeper meaning and interpretation of a text, a reader must access the final level which is the situation model level, also known as the integration level (Kintsch, 1998). A situation model is a mental representation of the situation described by a text (Kintsch, 1998; van Dijk \& Kintsch, 1983). It refers to the events, actions, and people described by a text. The construction of a situation model involves the combination of information found in the text with the reader's relevant prior knowledge. This combination will allow the reader to make inferences and access information that was not explicitly expressed in the text. If a reader has formed the correct text-base but is unable to integrate prior knowledge from memory with the new information provided by the text, this reader would have a more superficial understanding of the text because the situation model level was not reached and inferences were not made (Kintsch \& Rawson, 2005).

Reading comprehension relies on multiple cognitive functions such as memory, attentional resources, and other cognitive functions (De Beni, Borella, \& Carretti, 2007; Kendeou, Van Den Broek, Helder, \& Karlsson, 2014; Kintsch \& Rawson, 2005). Memory plays an important role in reading comprehension (Chesneau et al., 2007; De Beni et al., 2007; Ericsson \& Kintsch, 1995; Kendeou, et al., 2014; Kintsch \& Rawson, 2005). In order to comprehend a text, the reader must be able to hold information in his/her working memory while simultaneously extracting meaning from the following words and sentences in the text (De Beni et al., 2007). Research has shown that reading comprehension can be affected by working memory capacity. A greater memory capacity allows the reader to simultaneously engage in multiple reading processes (e.g. decoding new words, recalling previous sentences, making inferences, and anticipating what will happen next) (Daneman \& Carpenter, 1980; Kintsch \& van Dijk, 1978). Poor working memory capacity increases the risk that previously processed information will be forgotten, resulting in a lower text comprehension information (Daneman \& Carpenter, 1980; Kintsch \& van Dijk, 1978).

Other cognitive functions associated to reading comprehension include organizing and planning skills (Sesma, Mahone, Levine, Eason \& Cutting, 2009), attentional resources such as selective attention (Oakhill, Hartt, \& Samols, 2005), and inhibition (Kendeou et al., 2014). These cognitive functions allow information read in the text to be processed in order to form the text base and they also allow prior knowledge to be integrated in order to form the situation model (Chesneau et al., 2007; Ericsson \& Kintsch, 1995; Kendeou et al., 2014; Kintsch \& Rawson, 2005; Kintsch, Patel \& Ericsson, 1999).

The aging population presents a particularly high proportion of low literacy skills (Rootman and Ronson, 2005). The Canadian Council on Learning estimated that by 
Diversity of Research in Health Journal / Revue de la Diversité de la Recherche en Santé Vol 4, January/ Janvier 2021 - ISSN: 2561 -1666 DOI : 10.28984/drhj.v4i1.336

2031, 6.2 million Canadians over the age of 66 will have low literacy skills (Murray, Jones, Williams, Shillington, McCraken, \& Glickman, 2008). This alarming prediction highlights the need to further understand literacy abilities in the aging population in order to ensure that written information is accessible to this population.

Many cognitive functions involved in reading comprehension have been shown to decline with aging (Kobayashi, Wardle, Wolf, \& von Wagner, 2015). Several studies have demonstrated that this decline in cognitive abilities contributes to poor reading comprehension (Borella, Ghisletta, \& De Ribaupierre, 2011; De Beni, Palladino, Borella, $\&$ Presti, 2003; Kobayashi et al., 2015). Decline in working memory could contribute to age-related decline in reading comprehension abilities (Norman, Kemper \& Kynette, 1992; Silagi, Vivian, Leticia \& Radanovic, 2014; Van der Linden et al., 1999). Reduced working memory capacity in older individuals makes it more difficult to store information in their memory while extracting meaning from the next sentence in the text, hence, reducing their overall sentence comprehension (Norman et al., 1992). Moreover, the decline in cognitive functions - such as working memory and attention - affects the ability to make inferences and thus the performance in reading comprehension (Silagi et al., 2014). Although the types of text (e.g. narrative, expository) may play a role in reading comprehension (De Beni et al., 2007), difficulties seem to be prevalent after the age of 75 years old (Baltes \& Mayer, 1999; De Beni et al., 2007).

Several studies have shown that aging seems to affect reading comprehension abilities at the surface and text-based level, however, the situation model level seems to be relatively well preserved in older adults (Radvansky, 1999; Radvansky, Zwaan, Curiel \& Copeland, 2001; Radvansky \& Dijkstra, 2007). Younger adults usually demonstrate superior memory performance at the surface and text-based levels whereas older adults demonstrate superior memory performance at the situation model level (Radvansky et al., 2001; Stine-Morrow, Morrow, \& Leno, 2002). Radvansky et al. (2001) hypothesized that older adults have become more expert comprehenders therefore they are better able to select the information that is important for understanding and creating a situation model. Their experience allows them to be more selective of the information included in the situation model therefore contributing to the preservation of their abilities (Radvansky et al., 2001; Radvansky \& Dijkstra, 2007).

Several studies have indicated that educational history seems to be a predictor of cognitive change in aging adults (Christensen et al., 1997; Jacquim-Gadda, Fabrigoule, Commenges, \& Dartigues, 1997; Lee, Kawachi, Berkman, \& Grodstein, 2003). Many studies have reported a link between higher educational levels and lower risks of cognitive decline (Jacqmin-Gadda et al.,1997; Farmer, Kittner, Rae, Bartko, \& Regier, 1995; Lyketsos, Chen \& Anthony, 1999; Stern et al.,1994). Education plays a significant role in the evolution of cognitive abilities but the impact varies according to the age of the subject at the onset of impairment and the type of cognitive function measured (Leibovici, Ritchie, Ledésert, \& Touchon, 1996). Participation in lifestyle activities 
contributes to the association between cognitive performance and educational level. Several studies have stated that individuals with a higher educational attainment seem to have an increased participation in lifestyle activities (Hultsch, Hertzog, Small, \& Dixon, 1999; Lachman, Agrigoroaei, Murphy \& Tun, 2010; Schaie, 2005). Individuals with higher education seem to engage more frequently in cognitive activities such as reading, playing stimulating games, attending educational lectures or courses, and writing (Lachman et al., 2010; Parisi et al., 2012). Higher education and more frequent participation in cognitive activities are associated with better episodic memory and executive functioning (Hultsch et al., 1999; Lachman et al., 2010; Verghese et al., 2006; Wilson et al., 2002; Wilson et al., 2005). Several longitudinal studies support the cognitive enrichment hypothesis (Hultsch et al., 1999; Mackinnon, Christensen, Hofer, Korten, \& Jorm, 2003; Small \& McEvoy, 2008). According to this hypothesis, intellectually engaging activities promote enhancement and maintenance of cognitive functioning. The onset of cognitive decline is often postponed for individuals with high education level, occupational pursuits of high complexity, and high socioeconomic status (Schaie, 2005). Risk of cognitive decline is lower for individuals who are involved in intellectually engaging activities available in complex stimulating environments (Hultsch et al., 1999; Hultsch, Hammer, \& Small, 1993; Schaie, 2005).

Reading comprehension studies tend to consider the aging population as a homogenous group without examining the variability within this group. Studies examining reading comprehension variations in adults over the age of 75 are rare therefore there is a need to further examine the effect of aging on reading comprehension in older adults. De Beni et al. (2007) emphasized the importance of distinguishing age groups when studying the aging population because of the variability that can be found within this population. Furthermore, studies that examine the variability in the construction of a situation model in older adults are even more scarce and there is a lack of evidence that aging affects reading comprehension, particularly the situation model. Further understanding of the evolution of reading comprehension abilities in the aging population would give us the knowledge necessary to set standards with respect to reading comprehension in the typical aging population. These standards could then be used as a reference when studying atypical aging populations such as individuals with dementia. Knowledge on reading comprehension among different age groups will help develop proper recommendations to individuals and organizations conveying written information to the aging population. Written documents should be developed according to the aging population's literacy level in order to give them increased access to the information necessary to make informed decisions in their daily lives. Finally, it is important to raise awareness of the communication barrier created as a result of poor reading comprehension skills, which is directly related to a poor health status (Rootman \& Ronson, 2005). 
Diversity of Research in Health Journal / Revue de la Diversité de la Recherche en Santé Vol 4, January/ Janvier 2021 - ISSN: 2561 -1666 DOI : 10.28984/drhj.v4i1.336

The principal objective of this study was to examine the effect of age on reading comprehension abilities at the surface model, text-based model, and situation model in the aging population $(\geq 60)$ with a high level of education (2-4 years of post-secondary education). It is hypothesized that performance at the "surface" and "text-based" levels of reading comprehension will be poorer in the older group of adults because of deterioration of several cognitive functions. However, it is also hypothesized that reading comprehension performance at the "situation model" will not decline with age in older adults. Prior research has shown that performance at the situation model level seems to be relatively well preserved in older adults (Morrow, Leirer \& Altieri, 1992; Morrow, StineMorrow, Leirer, Andrassy \& Kahn, 1997; Radvansky, 1999; Radvansky, Copeland \& Zwaan, 2003; Stine-Morrow et al., 2002; Stine-Morrow, Gagne, Morrow \& De Wall, 2004).

\section{Method \\ Participants}

This study was approved by the Laurentian University Research Ethics Board and all participants signed an informed written consent prior to participating. A total of 20 participants were recruited in northeastern Ontario, Canada, through advertisements, social media, and in person presentations. Participants were grouped into three separate age intervals: 60 to 69 years of age ( $n=10 ; 2$ men and 8 women), 70-79 years of age ( $n=$ 7; 1 man and 6 women) and 80 years and older ( $n=3 ; 0$ men and 3 women). Participants were monolingual anglophones. They were required to have a minimum of two years of post-secondary education. Only non-cognitively impaired individuals were included in this study. The characteristics of the different groups are summarized in Table 1. Participants had between 13 to 17 years of education (Table 1). No significant differences were found in the number of years of education among the three age groups $(H(3)=$ 2.485, $p=0,289)$. Cognitive function was measured using the Montreal Cognitive Assessment (MoCA). No significant differences were found for the MoCA scores among the age groups $(H(3)=0.733, p=0.693)$. 
Diversity of Research in Health Journal / Revue de la Diversité de la Recherche en Santé Vol 4, January/ Janvier 2021 - ISSN: 2561 -1666 DOI : 10.28984/drhj.v4i1.336

Table 1: Characteristics of the Different Groups of Participants

\begin{tabular}{lccc}
\hline Age groups & $\begin{array}{c}60-69 \text { y/o } \\
(\mathrm{n}=10)\end{array}$ & $\begin{array}{c}70-79 \text { y/o } \\
(\mathrm{n}=7)\end{array}$ & $\begin{array}{c}>80 \mathrm{y} / \mathrm{o} \\
(\mathrm{n}=3)\end{array}$ \\
\hline Mean age (SD) & $64.40(2.914)$ & $74.14(2.673)$ & $85(5.292)$ \\
Sex (n) & 2 & 1 & 0 \\
Males & 8 & 6 & 3 \\
Females & & & $14.33(1.1555)$ \\
Years of education & $15.20(1.033)$ & $15.57(0.976)$ & \\
(SD) & &
\end{tabular}

Note. $\mathrm{SD}=$ standard deviation; $\mathrm{n}=$ sample size.

\section{Materials and Procedures}

Participants were required to attend two one-hour meetings between June and December 2019. The tests were administered by trained students from the bachelor and master's program of Speech-Language Pathology at Laurentian University (Sudbury, Ontario, Canada). Each meeting took place in a quiet room free of distractions. If participants wore glasses or hearing aids, they were instructed to put them on before starting the assessment. Participants completed a written questionnaire in order to provide demographic information and to answer questions pertaining to their reading habits. The Montreal Cognitive Assessment version 7.1 (MoCA) was administered in order to assess the individual's cognitive status (MoCA; Nasreddine et al., 2005). Two subtests from the Woodcock Reading Mastery Tests third edition (WRMT-III; Woodcock, 2011) were administered following the manual's administration and scoring guidelines, and using the stimulus book A. The first sub-test is the word comprehension test and it consists of three tasks: naming antonyms of written words; naming synonyms of written words; and completing analogies. The second sub-test was the passage comprehension task. Participants had to read a short passage and fill in the blanks. These subtests from the WRMT-III focus primarily on the surface and text-based levels of comprehension. The standard scores of each subtest and the cluster standard score of reading comprehension were used for statistical analyses. 
Diversity of Research in Health Journal / Revue de la Diversité de la Recherche en Santé Vol 4, January/ Janvier 2021 - ISSN: 2561 -1666 DOI : 10.28984/drhj.v4i1.336

In the second meeting functional health literacy was assessed using the Short Test of Functional Health Literacy in Adults (S-TOFHLA; Nurss, Parker, Williams, \& Baker, 2001). This test was administered following the directions for administration, scoring, and technical data available in the test manual. The S-TOFHLA consists of two functional health reading comprehension passages with 16 (for passage A) and 20 (for passage B) items using a modified cloze procedure. Each sentence contained a blank space and the participants chose the answer among a set of options (multiple choice) to correctly fill the blank. The total S-TOFHLA score was used for statistical analyses. Finally, the Gray Oral Reading Test, fifth edition (GORT-5; Wiederholt \& Bryan, 2012) was administered using modified administration guidelines.

Scoring respected the instructions from the test manual. Testing began at story 6 and concluded at story 16 (form A). The participants had to read each story out loud. For each story the participants were required to answer five comprehension questions that were read aloud by the test administrator. The GORT-5 examiner's manual states that a component of the testing process is to remove the story from the examinee before proceeding to the comprehension questions (Wiederholt \& Bryant, 2012). However, Borella et al. (2011) found that when older adults were able to review the text while answering comprehension questions, their performance at the surface and text-based levels of reading comprehension was better.

The authors found that by allowing readers to review the text while answering questions they created a testing condition closely resembling what occurs in everyday life therefore the effect of aging on reading comprehension abilities is lessened. Preventing the participants from reviewing the text, required the participants to answer the comprehension questions based on memory relying mostly on working memory and not necessarily comprehension itself. These findings suggest that age related differences in reading comprehension abilities may have been overestimated in most studies (Borella et al., 2011). Consequently, the method for this study was adapted so that participants could review the texts while answering the comprehension questions. The comprehension subtest from the GORT-5 assess the three levels of reading comprehension, namely the surface level, the text-based level and the situation model.

\section{Data Analysis}

The assessment of normality was performed on each age group using Kolmogorov-Smirnov (K-S) and Shapiro-Wilk tests. However, due to the small sample size, we were unable to perform the Kolmogorov-Smirnov test on the group of adults 80 years and older. Results of normality tests indicated that some of the data within groups was not normally distributed $(p<0.05)$. Non-parametric tests were therefore performed in order to analyze the data. Likelihood-ratio Chi-square tests were conducted to assess reading habits differences among the three age groups. Krukal-Wallis tests were conducted in order to assess the differences in reading comprehension abilities amongst 
Diversity of Research in Health Journal / Revue de la Diversité de la Recherche en Santé Vol 4, January/ Janvier 2021 - ISSN: 2561 -1666 DOI : 10.28984/drhj.v4i1.336

older adults according to different age ranges. All statistical analyses were performed in IBM SPSS statistics version 26.

\section{Results}

Data from the reading habits questionnaire indicated that reading frequency as well as the average reading time varied among the three age groups (Table 2). However, no significant difference was observed in reading frequency among the three age groups $\left(G^{2}=3.575, p=0.167\right)$. Although participants from the group aged 70-79 years appeared to read for shorter period of times on average compared to the other age groups (Table 2), no significant difference was observed among the three age groups $\left(G^{2}=5.642, p=0.228\right)$.

Table 2: Reading habits of the three age groups of participants

Reading frequency

\begin{tabular}{|c|c|c|c|c|c|c|c|}
\hline & $\begin{array}{l}\text { A few } \\
\text { times a } \\
\text { month }\end{array}$ & $\begin{array}{c}\text { A few times } \\
\text { a week }\end{array}$ & Everyday & $\begin{array}{c}\text { Less } \\
\text { than } 15 \\
\min \end{array}$ & $\begin{array}{c}15 \text { to } 29 \\
\min \end{array}$ & $\begin{array}{l}30 \text { to } 59 \\
\min \end{array}$ & $\begin{array}{c}\text { One hour } \\
\text { or more }\end{array}$ \\
\hline $\begin{array}{c}60-69 y / o \\
(n=10)\end{array}$ & $20 \%$ & $80 \%$ & $0 \%$ & $0 \%$ & $0 \%$ & $30 \%$ & $70 \%$ \\
\hline $\begin{array}{c}70-79 \text { y/o } \\
(n=7)\end{array}$ & $0 \%$ & $50 \%$ & $50 \%$ & $0 \%$ & $33.33 \%$ & $33.33 \%$ & $33.33 \%$ \\
\hline $\begin{array}{c}>80 \text { y/o } \\
(n=3)\end{array}$ & $0 \%$ & $0 \%$ & $100 \%$ & $0 \%$ & $0 \%$ & $33.33 \%$ & $66.67 \%$ \\
\hline
\end{tabular}

Note. $\mathrm{n}=$ sample size.

No significant differences were found among the different age groups for the STOHFLA scores, as well as the Word Comprehension scores, Passage Comprehension scores and overall Reading Comprehension standard scores on the WRMT-III (Table 3). However, when considering individual tasks of the WRMT-III, a significant difference was found for the antonyms task (Table 3). During this task, the group aged 60-69 years performed significantly better than the group aged 70-79 years (post hoc pairwise comparison adjusted $p=0.022$ ). Finally, no significant differences were found for the Comprehension Score of the GORT-5 among the three age groups (Table 3). 
Diversity of Research in Health Journal / Revue de la Diversité de la Recherche en Santé Vol 4, January/ Janvier 2021 - ISSN: 2561 -1666 DOI : 10.28984/drhj.v4i1.336

Table 3: Comparison of the mean scores for the health literacy and reading comprehension tests by age group

\begin{tabular}{|c|c|c|c|c|c|}
\hline & $\begin{array}{c}60-69 \text { y/o } \\
(n=10)\end{array}$ & $\begin{array}{c}70-79 \text { y/o } \\
(n=7)\end{array}$ & $\begin{array}{l}>80 \mathrm{y} / \mathrm{o} \\
(\mathrm{n}=3)\end{array}$ & $\begin{array}{c}\text { Kruskal } \\
\text { Wallis H }\end{array}$ & $\mathrm{p}$ value \\
\hline $\begin{array}{l}\text { S-TOHFLA score } \\
\text { (SD) }\end{array}$ & $\begin{array}{c}35.10 \\
(1,287)\end{array}$ & $\begin{array}{c}34.71 \\
(2.138)\end{array}$ & $\begin{array}{l}35.33 \\
(0.577)\end{array}$ & 0.043 & 0.979 \\
\hline $\begin{array}{l}\text { Antonyms score } \\
\text { (SD) }\end{array}$ & $\begin{array}{c}18.60 \\
(1.350)\end{array}$ & $\begin{array}{c}16.43 \\
(1.134)\end{array}$ & $\begin{array}{c}16 \\
(1.732)\end{array}$ & 8,984 & $0.011 *$ \\
\hline $\begin{array}{l}\text { Synonyms score } \\
\text { (SD) }\end{array}$ & $\begin{array}{c}17.40 \\
(2.066)\end{array}$ & $\begin{array}{c}17.57 \\
(2.440)\end{array}$ & $\begin{array}{l}19.33 \\
(2.082)\end{array}$ & 2,122 & 0.346 \\
\hline $\begin{array}{l}\text { Analogies score } \\
\text { (SD) }\end{array}$ & $\begin{array}{c}31.90 \\
(3.755)\end{array}$ & $\begin{array}{c}30.43 \\
(7.871)\end{array}$ & $\begin{array}{c}33 \\
(1.732)\end{array}$ & 0,085 & 0.959 \\
\hline $\begin{array}{l}\text { Word } \\
\text { comprehension } \\
\text { score (SD) }\end{array}$ & $\begin{array}{l}111.50 \\
(7.835)\end{array}$ & $\begin{array}{c}105.29 \\
(12.134)\end{array}$ & $\begin{array}{l}111.67 \\
(6.028)\end{array}$ & 1,329 & 0.515 \\
\hline $\begin{array}{l}\text { Passage } \\
\text { Comprehension } \\
\text { score (SD) }\end{array}$ & $\begin{array}{c}103.70 \\
(10.771)\end{array}$ & $\begin{array}{c}87.57 \\
(36.013)\end{array}$ & $\begin{array}{l}103.67 \\
(9.074)\end{array}$ & 1,247 & 0.536 \\
\hline $\begin{array}{l}\text { Reading } \\
\text { comprehension } \\
\text { score (SD) }\end{array}$ & $\begin{array}{l}107.90 \\
(9.073)\end{array}$ & $\begin{array}{c}103.00 \\
(10.599)\end{array}$ & $\begin{array}{l}108.00 \\
(6.928)\end{array}$ & 0,944 & 0.624 \\
\hline $\begin{array}{l}\text { GORT-5 } \\
\text { Comprehension } \\
\text { score (SD) }\end{array}$ & $\begin{array}{l}68.20 \\
(5.514)\end{array}$ & $\begin{array}{c}65.29 \\
(4.071)\end{array}$ & $\begin{array}{c}68 \\
(1.00)\end{array}$ & 0,944 & 0.357 \\
\hline
\end{tabular}

Note. $\mathrm{SD}=$ standard deviation; $\mathrm{n}=$ sample size, * statistically significant at $\mathrm{p}<0.05$. 
Diversity of Research in Health Journal / Revue de la Diversité de la Recherche en Santé Vol 4, January/ Janvier 2021 - ISSN: 2561 -1666 DOI : 10.28984/drhj.v4i1.336

\section{Discussion}

This study examined the relationship between aging and reading comprehension abilities in individuals with post-secondary education. It was hypothesized that performance at the "surface" and "text-based" level of reading comprehension will be poorer in the older group of adults because of deterioration of several cognitive functions such as working memory and metacomprehension skills (De Beni et al., 2007).

The second hypothesis stipulated that reading comprehension at the "situation model" would not decline with age in older adults. Previous research has shown that performance at the situation model level seems to be relatively well preserved in older adults (Morrow et al., 1992; Morrow et al., 1997; Radvansky, 1999; Radvansky et al., 2003; Stine-Morrow et al., 2002; Stine-Morrow et al., 2004). Older adults' experience with reading comprehension should have taught them to invest more resources at the situation model level in order to compensate for loss of cognitive functions required for lower level processing (Radvansky et al., 2001; Stine-Morrow et al., 2002).

As expected, performance on reading comprehension tasks at the situation model level across age groups was similar and no significant differences were found at this level. However, contrary to what was expected we did not find significant differences in performance on reading comprehension tasks at the surface level and text-based level of reading comprehension. Older adults in this study did not demonstrate lower reading comprehension abilities.

The results obtained at the situation model level are consistent with results from multiple studies that have also found that situation model level performance of older adults is similar and in some case superior to the performance of younger adults (Morrow et al.,1992; Morrow et al., 1997; Radvansky, 1999; Radvansky et al., 2003; StineMorrow et al., 2002; Stine-Morrow et al., 2004). Morrow et al. (1997) found that adults adapted their resource allocation strategies to accommodate declines in the cognitive resources necessary to create situation models. They used similar strategies as younger adults such as slowing down reading to update the situation models from narratives, resulting in models that were equally as accurate as ones from younger adults. More successful older adults allocated more time for a reinstatement search, resulting in a more accurate model that facilitated answering the comprehension questions.

Individuals from our study had an unlimited amount of time to review the text in order to answer comprehension questions, therefore it is possible that they were able to create a more accurate situation model. Also, it is possible that our study did not reveal any differences at the situation model because of the age groups we were comparing. Most studies on the situation model compared younger and older adults whereas this study compared individuals within the aging population. Finally, Radvansky et al. (2001), explained that the experience of older adults (adults 60 to 87 years old) allows them to be more selective of the information included in the situation model therefore contributing to the preservation of their abilities. Our study may have yielded similar results because all 
Diversity of Research in Health Journal / Revue de la Diversité de la Recherche en Santé Vol 4, January/ Janvier 2021 - ISSN: 2561 -1666 DOI : 10.28984/drhj.v4i1.336

three of our age groups were considered older adults in the study led by Radvansky et al. (2001) and have performed similarly.

Regarding the surface level and text-based level, Borella and et al. (2011) explained that the effect of age on reading comprehension abilities may have been overestimated in most studies. They found that the absence of the text in the retrieval phase taxes more processing resources and memory, both known to decline in the aging population. When the support from the text is removed, researching strategies are not accessible to the reader to compensate for deficient encoding. The performance of older adults was improved when they were able to review the text when answering questions (Borella et al., 2011). These testing conditions more closely resembled an everyday life situation, therefore demands on working memory was lessened when answering the questions and age-related differences were attenuated. Similarly, adults who participated in our study were able to review the text when answering comprehension questions which could explain why they performed better on text dependent questions. Individuals did not have to rely on cognitive functions such as working memory and attentional resources to answer questions, they were able to use environmental support during the retrieval phase as well as researching strategies to improve their ability to answer comprehension questions.

Research has demonstrated that there is a link between cognitive functions and literacy skills (Chesneau et al., 2007; Kintsch \& Rawson, 2005; Ericsson \& Kintsch 1995; Kintsch et al., 1999, Borella et al., 2011; Kobayashi et al., 2015; Silagi et al., 2014). Cognitive functions such as working memory decline with age, potentially reducing reading comprehension abilities (Kobayashi et al., 2015; Borella et al., 2011). Poor reading comprehension has been linked to a decline in working memory (Borella et al., 2011, De Beni et al., 2007) as well as poor metacognitive skills (De Beni et al., 2003, De Beni et al., 2007). However, the results from this study indicated no significant differences in reading comprehension abilities among the different groups of aging adults. The lack of differences may be explained by the absence of differences in cognitive function between the three age groups as indicated by similar scores on the MoCA test. These findings may also be the result of the high level of education of our participants as we compared groups of educated adults who have between 13 and 17 years of education.

Several studies have indicated that educational background seems to be a predictor of cognitive change (Christensen et al, 1997; Jacquim-Gadda et al., 1997; Lee et al., 2003; Lyketsos et al., 1999). Many studies have reported a link between higher educational levels and lower risks of cognitive decline (Jacqmin-Gadda et al.,1997; Farmer et al., 1995; Lyketsos et al., 1999; Stern et al, 1994). Leibovici et al. (1996) found that education does play a significant role in the evolution of cognitive deficit but the impact varies according to the age of the subject at the onset of impairment and the type of cognitive function measured. They determined that elderly adults with a high level of 
Diversity of Research in Health Journal / Revue de la Diversité de la Recherche en Santé Vol 4, January/ Janvier 2021 - ISSN: 2561 -1666 DOI : 10.28984/drhj.v4i1.336

education appear to show more resistance to change in tests measuring language and secondary memory. These findings may explain the absence of difference found in reading comprehension abilities among the groups from this study. All the participants from this study had between 13 and 17 years of education which may explain why no differences in performance were detected.

Most of the participants in this study read every day. These reading habits may also explain the lack of differences observed in levels of reading comprehension. However, when analyzing the antonyms task from the WRMT-III, significant differences were found among age groups. The group aged 60-69 years old performed better than the group aged 70-79 years old in the antonyms task. This difference in performance could be explained by the variations observed in average reading time among age groups. Although each participant reported that they read frequently and no significant difference was detected among the groups, the group aged 60-69 years of age appeared to read for longer periods of time when compared to adults aged 70-79 years of age. The lack of significant difference may be the result of the small sample size. Errors on the antonyms task were not further analyzed in this study. Therefore, it is unknown whether more errors from the participants were made based on words frequency or on the types of words (e.g. nouns, verbs or adjectives). Future research on the subject would be required in order to better understand performance at the antonym level, and to see if exposure to reading can have an effect on the capacity of generating antonyms.

Several studies have stated that individuals with a higher educational attainment, which is the case for the individuals from this study, seem to have an increased participation in cognitively demanding activities (Hultsch et al., 1999; Schaie, 2005; Lachman et al., 2010) which in turn is associated with better cognitive functioning. The participants of this study reported reading different types of reading material such as books, newspapers as well as dictionaries for activities such as crossword puzzles. All these types of reading activities qualify as cognitively demanding activities. Hultsch et al. (1999) found that intellectually engaging activities buffer against longitudinally measured cognitive decline. Furthermore, Parisi et al. (2012) found that higher educational level was related to better cognitive measures as well as a more frequent report of intellectual activities such as reading, crossword puzzles, taking classes-courses and physical activities. Individuals with a higher educational level seem to be more likely to participate in intellectually demanding activities therefore these individuals are continuously placing significant demands on their intellectual resources resulting in a maintained or even enhanced cognitive function (Parisi et al., 2012). Again, individuals in this study were highly educated and most reported reading daily. These findings could explain, in part, why declines in reading comprehension abilities of older adults were not observed in this study. 
Diversity of Research in Health Journal / Revue de la Diversité de la Recherche en Santé Vol 4, January/ Janvier 2021 - ISSN: 2561 -1666 DOI : 10.28984/drhj.v4i1.336

\section{Limitations}

The first limit of this study is the small sample size and the uneven samples per group. This is particularly true for the group of individuals aged 80 and over. A larger sample size and an even distribution of individuals per group would give more statistical power to the results observed. An additional limit regarding the sample size is the unbalanced sex ratio that is biased towards females (only 15\%, were males). Sex disparities have been shown in reading performance and motivation with females performing better than males (Frijters, Brown, \& Greenberg, 2019). This sex difference may have played a role in the motivation to participate in this study.

Another limit of the study is the availability of tests to measure reading comprehension at the different comprehension levels, particularly the situation model level, as reading comprehension tests developed for adults are limited. Although the GORT-5 was standardized and normalized for individuals from 6 to 24 years of age, this test met the criteria required for this study. Finally, the GORT-5 contained mostly narrative texts. Depending on individual reading habits, it is possible that participants were not accustomed to reading this type of texts therefore other types of texts should be included in future studies.

\section{Future directions}

Further research would be beneficial in order to better understand the relationship between aging, education, and reading comprehension abilities. This study should be replicated with a larger sample size as well as a balanced sex ratio, and with a focus on characteristics that are seemingly linked to aging and cognition such as lifestyle activities, level of education, and socioeconomic status. This would allow a better understanding of which characteristics are specifically associated with reading comprehension abilities in the aging population.

Furthermore, this study focused on comparing reading comprehension abilities in different age groups of educated anglophone adults. Future studies should examine reading comprehension in anglophone adults who did not obtain post-secondary education. This would help to better understand whether education is truly a protective factor against a decline in reading comprehension abilities.

Finally, future research on the effect of aging on reading comprehension abilities should include the use of different types of texts. As previously mentioned the GORT-5 contained mostly narrative texts. It would be interesting to include other types of texts such as expository texts, argumentative texts, or non-fiction texts in order to compare individual performance in reading comprehension with different types of texts.

\section{Conclusion}

The main objective of this study was to examine the effect of age on reading comprehension abilities at the surface model, text-based model, and situation model in the aging population $(\geq 60)$ with a high level of education $(2-4$ years of post-secondary 
Diversity of Research in Health Journal / Revue de la Diversité de la Recherche en Santé Vol 4, January/ Janvier 2021 - ISSN: 2561 -1666 DOI : 10.28984/drhj.v4i1.336

education). The results of this study showed no evidence of an age-related decline of reading comprehension abilities. These findings were attributed to individuals' level of education as well as participation in intellectual lifestyle activities. Findings from this study contribute to a better understanding of reading comprehension abilities in the aging population. Future studies will be required in order to better understand the complex relationship between aging, cognition, education, and reading comprehension.

\section{Acknowledgments}

We thank the 20 participants who contributed to this research. We thank Sophie Laurin for her help in data collection. We also thank Michèle Minor-Corriveau for her helpful comments.

\section{References}

Baltes, P. B., \& Mayer, K. U. (1999). The Berlin Aging Study: Aging from 70 to 100. New York, NY, US: Cambridge University Press.

Borella, E., Ghisletta, P., \& De Ribaupierre, A. (2011). Age differences in text processing: The role of working memory, inhibition, and processing speed. The Journals of Gerontology Series B: Psychological Sciences and Social Sciences, 66(3), 311-320. doi:10.1093/geronb/gbr002

Chesneau, S., Roy, M. C., \& Ska, B. (2007). Évaluation de la compréhension de textes narratifs construits selon un modèle théorique. Revue Canadienne D'orthophonie et d'Audiologie-Vol, 31(2), 83-90.

Christensen, H., Korten, A. E., Jorm, A. F., Henderson, A.S., Jacomb, P.A., Rodgers, B., \& Mackinnon, A. J. (1997). Education and decline in cognitive performance:

Compensatory but not protective. International Journal of Geriatric Psychiatry, 12, 323-330. doi: 10.1002/(SICI)1099-1166(199703)12:3<323::AID-

GPS492>3.0.CO;2-N

Daneman, M., \& Carpenter, P. A. (1980). Individual differences in working memory and reading. Journal of Verbal Learning and Verbal Behavior, 19, 450-466.

De Beni, R., Borella, E., \& Carretti, B. (2007). Reading comprehension in aging: The role of working memory and metacomprehension. Aging, Neuropsychology, and Cognition, 14(2), 189-212. doi:10.1080/13825580500229213

De Beni, R., Palladino, P., Borella E. \& Presti., S. (2003) Reading comprehension and aging: Does an age-related difference necessarily mean impairment? Aging Clinical and Experimental Research, 15(1), 67-76. doi:10.1007/BF03324482.

Ericsson, K. A., \& Kintsch, W. (1995). Long-term working memory. Psychological Review, 102(2), 211-245. doi:10.1037/0033-295X.102.2.211 
Diversity of Research in Health Journal / Revue de la Diversité de la Recherche en Santé Vol 4, January/ Janvier 2021 - ISSN: 2561 -1666 DOI : 10.28984/drhj.v4i1.336

Farmer, M. E., Kittner, S. J., Rae. D. S., Bartko, J. J., \& Regier, D. A. (1995). Education and change in cognitive function: The epidemiologic catchment area study. Annals of Epidemiology, 5(1), 1-7.

Frijters, J. C., Brown, E., \& Greenberg, D. (2019). Gender Differences in the Reading Motivation of Adults with Low Literacy Skills. The Wiley Handbook of Adult Literacy, 63-87.

Hultsch, D. F., Hammer, M., \& Small, B. J. (1993). Age differences in cognitive performance in late life: Relationships to self-reported health and activity style. Journal of Gerontology, 48(1), 1-11. doi:10.1093/geronj/48.1.P1

Hultsch, D.F., Hertzog, C., Small, B.J., \& Dixon, R.A. (1999). Use it or lose it: Engaged lifestyle as a buffer of cognitive decline in aging? Psychology and Aging, 14, 245263. doi: 10.1037/0882-7974.14.2.245

Jacquim-Gadda, H., Fabrigoule, C., Commenges, D., \& Dartigues, J. (1997). A 5-year longitudinal study of the mini-mental state examination in normal aging. American Journal of Epidemiology, 145(6), 498-506. doi: 10.1093/oxfordjournals.aje.a009137

Kendeou, P., Van Den Broek, P., Helder, A., \& Karlsson, J. (2014). A cognitive view of reading comprehension: Implications for reading difficulties. Learning Disabilities Research \& Practice, 29(1), 10-16. doi: doi.org/10.1111/ldrp.12025

Kintsch, W. (1998). Comprehension: A paradigm for cognition. New York, NY: Cambridge university press.

Kintsch, W., \& Rawson, K. A. (2005). Comprehension. In M.J. Snowling \& C. Hulme (Eds), The science of reading: A handbook. (pp.209-226). Malden, MA: Blackwell

Kintsch, W., \& Van Dijk, T. A. (1978). Toward a model of text comprehension and production. Psychological review, 85(5), 363. doi:10.1037/0033-295X.85.5.363

Kintsch, W., Patel, V.L., \& Ericsson, K.A. (1999). The role of long-term working memory in text comprehension. Psychologica, 42(4), 186-198.

Kobayashi, L., Wardle, J., Wolf, M., \& Wagner, C. (2015). Cognitive function and health literacy decline in a cohort of aging english adults. Journal of General Internal Medicine, 30(7), 958-964. doi.org/10.1007/s11606-015-3206-9

Lachman, M. E., Agrigoroaei, S., Murphy, C., \& Tun, P. A. (2010). Frequent cognitive activity compensates for education differences in episodic memory. The American Journal of Geriatric Psychiatry, 18(1), 4-10. doi: 10.1097/JGP.0b013e3181ab8b62

Lee, S., Kawachi, I., Berkman, L. F., \& Grodstein, F. (2003). Education, other socioeconomic indicator, and cognitive function. American Journal of Epidemiology, 157(8), 712-720. doi: 10.1093/aje/kwg042

Leibovici, D., Ritchie, K., Ledesert, B., \& Touchon, J. (1996). Does education level determine the course of cognitive decline? Age and Ageing, 25(5), 392-397. doi:10.1093/ageing/25.5.392 
Diversity of Research in Health Journal / Revue de la Diversité de la Recherche en Santé Vol 4, January/ Janvier 2021 - ISSN: 2561 -1666 DOI : 10.28984/drhj.v4i1.336

Lyketsos, C.G., Chen, L.S., \& Anthony, J.C. (1999). Cognitive decline in adulthood: An 11.5 year follow-up of the baltimore epidemiologic catchment area study. American Journal of Psychiatry, 156(1), 58-65. doi:10.1176/ajp.156.1.58

Mackinnon, A., Christensen, H., Hofer, S. M., Korten, A. E. \& Jorm, A. F. (2003). Use it and still lose it? The association between activity and cognitive performance established using latent growth techniques in a community sample. Aging, Neuropsychology, and Cognition, 10(3), 215-229. doi: 10.1076/anec.10.3.215.16451

Morrow, D. G., Leirer, V. O. \& Altieri, P.A. (1992). Aging, expertise and narrative processing. Psychology and Aging, 7(3), 376-388. doi:/10.1037/0882-7974.7.3.376

Morrow, D. G., Stine-Morrow, E. A. L., Leirer, V. O., Andrassy, J. M., \& Kahn, J. (1997). The role of reader age and focus of attention in creating situation models from narratives. Journal of Gerontology: Psychological Sciences, 52B, 73-80. doi:10.1093/geronb/52B.2.P73

Murray, T. S., Jones, S., Willams, D., Shillington, R., McCracken, M., \& Glickman, V. (2008). Reading the future: Planning to meet Canada's future literacy needs. Ottawa, ON: Canadian Council on Learning.

Nasreddine, Z. S., Phillips, N. A., Bédirian, V., Charbonneau, S., Whitehead, V., Collin, I., .... Chertkow, H. (2005). The Montreal Cognitive Assessment, MoCA: A brief screening tool for mild cognitive impairment. Journal of the American Geriatrics Society, 53(4), 695-699. doi: 10.1111/j.1532-5415.2005.53221.x

Norman, S., Kemper, S., \& Kynette, D. (1992). Adults' reading comprehension: Effects of syntactic complexity and working memory. Journal of Gerontology, 47(4), 258265. doi: 10.1093/geronj/47.4.P258

Nurss, J. R., Parker, R. M., Williams, M. V., \& Baker, D. W. (2001). TOFHLA: Test of functional health literacy in adults. Hartford, MI: Peppercorn Books \& Press, Inc.

Oakhill, J., Hartt, J., \& Samols, D. (2005). Levels of comprehension monitoring and working memory in good and poor comprehenders. Reading and Writing, 18(7-9), 657-686.

Parisi, J. M., Rebok, G. W., Xue, Q. L., Fried, L. P. Seeman, T. E., Tanner, E. K. ...\& Carlson, M. C. (2012). The role of education and intellectual activity on cognition. Journal of Aging Research, 2012. doi: 10.1155/2012/416132

Peng, J., Valpreda, M., \& Lechelt, K. (2015). Health literacy: Improving communication between health care practitioners and older adults. Canadian Geriatrics Society Journal of CME, 5(2), 21-30.

Radvansky, G. A. (1999). Memory retrieval and suppression: The inhibition of situation models. Journal of Experimental Psychology: General, 128(4), 563-579. doi:10.1037/0096-3445.128.4.563 
Diversity of Research in Health Journal / Revue de la Diversité de la Recherche en Santé Vol 4, January/ Janvier 2021 - ISSN: 2561 -1666 DOI : 10.28984/drhj.v4i1.336

Radvansky, G. A., Copeland, D. E., \& Zwaan, R. A. (2003). Aging and functional spatial relations in comprehension and memory. Psychology \& Aging, 18, 161-165. doi: 10.1037/0882-7974.18.1.161

Radvansky, G. A., \& Dijkstra, K., (2007). Aging and situation model processing. Psychonomic Bulletin \& Review, 14(6), 1027-1042.

Radvansky, G. A., Zwaan, R. A., Curiel, J. M. \& Copeland, D. E. (2001) Situation models and aging. Psychology and Aging, 16(1), 145-60. doi.org/10.1037/08827974.16.1.145.

Rootman, I., \& Ronson, B. (2005). Literacy and health research in Canada: Where have we been and where should we go? Canadian Journal of Public Health, 96, S62S77. doi: 10.1007/BF03403703

Schaie, W. (2005). Developmental influences on adult intelligence: The Seattle ongitudinal study. Oxford University: Oxford University Press.

Seccombe, K., Lockwood, R. S., \& Reder, S. (2005). Literacy: Influence on access and use of the health care system. Research in the Sociology of Health Care, 23, 277295. doi:10.1016/S0275-4959(05)23013-2

Sesma, H. W., Mahone, E. M., Levine, T., Eason, S. H., \& Cutting, L. E. (2009). The contribution of executive skills to reading comprehension. Child Neuropsychology, 15(3), 232-246. doi: 10.1080/09297040802220029

Silagi, M. L., Vivian U. R., Leticia L. M. \& Radanovic, M. (2014) Inference comprehension during reading: Influence of age and education in normal adults. CoDAS, 26(5), 407-414. doi:10.1590/2317-1782/20142013058.

Small, B. J., \& McEvoy, C. L. (2008). Does participation in cognitive activities buffer age-related cognitive decline? In S. M. Hofer \& D. F. Alwin (Eds.), Handbook of Cognitive Aging: Interdisciplinary Perspectives (p. 575-586). Sage Publications, Inc. doi: 10.4135/9781412976589.n34

Stern, Y., Gurland, B., Tatemichi, T. K., Tang, M. X., Wilder, D., \& Mayeux, R. (1994). Influence of education and occupation on the incidence of Alzheimer's disease. JAMA, 271(12), 1004-1010. doi: 10.1001/jama.1994.03510370056032

Stine-Morrow, E. A. L., Gagne, D. D., Morrow, D. G., \& De Wall, B. H. (2004). Age differences in rereading. Memory \& Cognition, 32, 696-710. Retrieved from https://link.springer.com/article/10.3758/BF03195860

Stine-Morrow, E. A. L., Morrow, D. G., \& Leno, R. (2002). Aging and the representation of spatial situations in narrative understanding. The Journals of Gerontology: Series B, 7(4), 291-297. doi:10.1093/geronb/57.4.P291

Stormacq, C., Van den Broucke, S., \& Wosinski, J. (2019). Does health literacy mediate the relationship between socioeconomic status and health disparities? Integrative review. Health Promotion International, 34(5), e1-e17. doi :

10.1093/heapro/day062 
Diversity of Research in Health Journal / Revue de la Diversité de la Recherche en Santé Vol 4, January/ Janvier 2021 - ISSN: 2561 -1666 DOI : 10.28984/drhj.v4i1.336

Van der Linden, M., Hupet, M., Feyereisen, P., Schelstraete, M. A., Bestgen, Y., Bruyer, R., .. \& \& Seron, X. (1999). Cognitive mediators of age-related differences in language comprehension and verbal memory performance. Aging, Neuropsychology, and Cognition, 6(1), 32-55. doi:10.1076/anec.6.1.32.791

van Dijk, T. A., \& Kintsch, W. (1983). Strategies of discourse comprehension. New York: Academic Press.

Verghese, J., LeValley, A., Derby, C., Kuslansky, G., Katz, M., Hall, C., Buschke, H., Lipton, R. B. (2006). Leisure activities and the risk of amnestic mild cognitive impairment in the elderly. Neurology, 66(6) 821-827.

Wiederholt, J. L. \& Bryant, B. R. (2012). Gray Oral Reading Test (5 ${ }^{\text {th }}$ ed.). Austin, TX: pro-ed.

Wilson, R. S., Barnes, L. L., Krueger, K. R., Hoganson, G. Bienias, J. L., \& Bennett, D. A. (2005). Early and late life cognitive activity and cognitive systems in old age. Journal of the International Neuropsychological Society, 11(4), 400-407.

Wilson, R. S., De Leon, C. F. M., Barnes, L. L., Schneider, J.A., Bienias, J. L. Evans, D. A., \& Bennett, D. A. (2002). Participation in cognitively stimulating activities and risk of incident Alzheimer disease. JAMA, 287(6), 742-748. doi: 10.1001/jama.287.6.742

Woodcock, R. W. (2011). Woodcock Reading Mastery Tests (3rd ed.). San Antonio, TX: PsychCorp.

Zheng, M., Jin, H., Shi, N., Duan, C., Wang, D., Yu, X., \& Li, X. (2018). The relationship between health literacy and quality of life: a systematic review and meta-analysis. Health and Quality of Life Outcomes, 16(1), 1-10. doi : 10.1186/s12955-018-1031-7 